Research Papers

\title{
Effect of pH on the Adsorption and Desorption of Human Serum Albumin at Titanium-Water Interfaces
}

\author{
Kazuhiro TAKAHASHI ${ }^{a}$ and Satoshi FUKUZAKI ${ }^{\mathrm{a}, *}$
}

${ }^{a}$ Industrial Technology Center of Okayama Prefecture(5301 Haga, Kita-ku, Okayama-shi, Okayama 701-1296)

\begin{abstract}
Adsorption and desorption behaviors of human serum albumin (HSA) on titanium particles were examined as a function of $\mathrm{pH}$. The HSA showed a high affinity-type isotherm with well-defined saturation values, even when HSA had a net charge that was the same type as that of titanium. The saturated amount of HSA adsorbed $\left(\Gamma_{\text {sat }}\right)$ depended on $\mathrm{pH}$. The maximum value of $\Gamma_{\text {sat }}$ was obtained at $\mathrm{pH}$ around the apparent point of zero charge of HSA, where the net charge $\left(Z_{\mathrm{H}^{+} \text {app }}\right)$ of HSA was zero and where HSA has the minimum intrinsic viscosity $([\eta])$, reflecting the molecular volume. Results showed that the $Z_{\mathrm{H}^{+}}$app and $[\eta]$ of HSA are the most important factors determining the $\Gamma_{\text {sat }}$ value. Curves for the surface charge density $\left(\sigma_{\text {app }}\right)$ of HSA-adsorbed titanium prepared at initial $\mathrm{pH} 7.4$ showed that carboxyl groups on HSA contributed to interactions even with the negatively charged titanium surfaces. The possible interactions between ionic functional groups on HSA and titanium were discussed based on measurements of variation in $\mathrm{pH}$ of solutions, i.e., uptake or release of proton $(\Delta \mathrm{pH})$ as a result of adsorption. The removal of HSA from titanium surfaces was more rapid when using alkaline solutions, particularly at $\mathrm{pH}$ greater than 11. Results showed that HSA was adsorbed onto titanium surfaces, even under unfavorable electrostatic conditions, through various interactions between ionic groups on HSA and surface OH groups on titanium, the magnitude of those interactions was diminished by the $\mathrm{OH}^{-}$cleaning action.
\end{abstract}

Keywords : Human Serum Albumin, Adsorption Interactions, Net Proton Charge, Intrinsic Viscosity, Surface Charge Density

\section{Introduction}

The adsorption behavior of proteins at solid-liquid interfaces is a subject of great importance, particularly in reference to fouling, in biochemical fields. In the medical area, when medical device surface comes in contact with blood, its surface is spontaneously covered with components of blood, including proteins. Human serum albumin (HSA) is recognized as a major protein in blood ( $4 \%$ in blood plasma) and it tends to be spontaneously adsorbed on medical device and implant surface, thereby constructing the conditioning film ${ }^{1)}{ }^{3}$. The conditioning film alters the physicochemical properties of the solid surfaces, and also plays a mediating role in bacterial adhesion. A bacterial infection presents a serious problem especially in the medical area ${ }^{4)}$. To control and minimize protein adsorption and the formation of the conditioning film, it is necessary to elucidate the mode of initial adsorption of HSA onto the blood-contact surfaces.

Metallic titanium has been widely used for the medical device and the dental instrument because of excellent corrosion resistance, mechanical properties, and biocompatibility ${ }^{5), 6}$. It is known that surface of metallic titanium are covered with stable oxide films, e.g., $\mathrm{TiO}_{2}$, on which hydroxyl groups ( $\mathrm{OH}$ groups) are formed through chemisorption of water molecules ${ }^{7) \sim 9)}$. These $\mathrm{OH}$ groups were distinguished between the acidic $\mathrm{OH}$ groups $\left(-\mathrm{Ti}_{2} \mathrm{OH}\right)$ and basic $\mathrm{OH}$ groups $(-\mathrm{TiOH})$ depending on the number of coordination to titanium ion. Titanium surface shows an amphoteric nature and its surface charge density and polarity vary as a function of $\mathrm{pH}$. The surface $\mathrm{OH}$ groups on titanium play a role in adsorption sites for organic and inorganic materials ${ }^{9)}$. HSA also has both positively (e.g., $-\mathrm{NH}_{3}{ }^{+}$) and negatively charged groups (e.g., $-\mathrm{COO}^{-}$), and its net charge and

*E-mail: satoshi_fukuzaki@pref.okayama.lg.jp molecular volume in solution varies widely depending on the solution $\mathrm{pH}$. It is thought that the type and magnitude of the predominant interaction between HSA and titanium are also strongly affected by the solution $\mathrm{pH}$. Although many researchers have studied the adsorption behavior of HSA at solid-liquid interfaces from the viewpoint of electrostatic interaction ${ }^{1,10)}{ }^{12}$, our fundamental understanding of the mode of initial adsorption of HSA onto titanium surface is still lacking.

The purpose of this study is two fold: (i) to elucidate the factors determining the amount of HSA adsorbed on titanium, forming a first monolayer, and (ii) to discuss the type of interaction between HSA and titanium. The adsorption behavior of HSA at water-titanium interfaces was studied as a function of $\mathrm{pH}$. The electrostatic properties of HSA, titanium, and HSA-adsorbed titanium were measured by the potentiometric titration. We show here that the amount of HSA adsorbed on titanium is largely determined by the net charge of HSA, and that ionic functional groups on HSA molecule involved in the irreversible adsorption through electrostatic interaction, hydrogen binding, or ligand exchange with surface $\mathrm{OH}$ groups on titanium are proposed as a function of $\mathrm{pH}$.

\section{Experimental}

\section{1 Materials and chemicals}

Nonporous titanium particles (Lot 054370) were obtained from Kojundo Chemical Laboratory Co. Ltd (Saitama). The specific surface area and mean diameter of titanium particles were $0.9 \mathrm{~m}^{2} / \mathrm{g}$ and $10 \mu \mathrm{m}$, respectively. Prior to the use, titanium particles were washed with acetone and ethanol with sonication for $15 \mathrm{~min}$, and then dried at $40{ }^{\circ} \mathrm{C}$. Human serum albumin (HSA) (Fraction V, A-1653, Lot 072K7601) was purchased from Sigma-Aldrich Co. (St. Louis, Mo) and used as received. All other chemicals were of analytical grade. 


\section{2 Measurements of charges of HSA and titanium particles}

The apparent values of the net proton charge of HSA $\left(Z_{\mathrm{H}^{+}}\right.$app $)$ and the surface charge density of titanium particles $\left(\sigma_{\text {app }}\right)$ were measured in the presence of $\mathrm{KNO}_{3}$, which is an indifferent electrolyte, using a potentiometric titrator (GT-07, Mitsubishi Chemical Ind. Ltd., Tokyo) ${ }^{8), 13)}$. In this study, $0.1 \mathrm{dm}^{3}$ of $10^{-1} \mathrm{M}$, $10^{-2} \mathrm{M}$, and $10^{-3} \mathrm{M} \mathrm{KNO}_{3}$ solutions (reference solution, $\mathrm{pH} 3.5$ ) were titrated with $0.1 \mathrm{M} \mathrm{KOH}$ to $\mathrm{pH} 9$ under $\mathrm{N}_{2}(99.999 \%$, $\mathrm{vol} / \mathrm{vol})$ ambience. Then, a $0.1 \mathrm{~g}$ of HSA or a $2.0 \mathrm{-g}$ aliquot of titanium particles was dissolved or suspended in $0.1 \mathrm{dm}^{3}$ of the $\mathrm{KNO}_{3}$ solution $(\mathrm{pH} 3.5)$, and the solution or suspension was titrated as described above. The difference between the amounts of $\mathrm{KOH}$ necessary to produce the same $\mathrm{pH}$ value in the reference solution and the solution or suspension was attributed to the relative adsorption of $\mathrm{H}^{+}$and $\mathrm{OH}^{-}\left(\left[\Gamma_{\mathrm{H}^{+}}-\Gamma_{\mathrm{OH}^{-}}\right]\right)$onto HSA or titanium surfaces. The $Z_{\mathrm{H}^{+} \text {app }}$ and $\sigma_{\text {app }}$ were calculated from $\left[\Gamma_{\mathrm{H}^{+}}\right.$ $\left.-\Gamma_{\mathrm{OH}^{-}}\right]$as a function of $\mathrm{pH}^{8,13)}$. If the intersection of curves for $Z_{\mathrm{H}^{+}}$app or $\sigma_{\text {app }}$ at three different $\mathrm{KNO}_{3}$ concentrations is obtained at a single $\mathrm{pH}$ value, this $\mathrm{pH}$ is regarded as the common intersection point ${ }^{14)}$, where $\left[\Gamma_{\mathrm{H}^{+}}-\Gamma_{\mathrm{OH}^{-}}\right]$is zero. Accordingly, this $\mathrm{pH}$ is regarded as the apparent point of zero charge ( $\mathrm{pzc}_{\text {app }}$ ).

\section{3 Intrinsic viscosity of HSA}

Specific viscosities $\left(\left[\eta_{\mathrm{sp}}\right]\right)$ of HSA at various concentrations $(c)$ of 4 to $30 \mathrm{~g}$ per $\mathrm{dm}^{3}$ of $10^{-3} \mathrm{M} \mathrm{KNO}_{3}$ solution were measured at $40{ }^{\circ} \mathrm{C}$ in the $\mathrm{pH}$ range of 3.6 to 7.4 by using an Ostwald viscometer $^{15)}$. The intrinsic viscosity $([\eta])$ was obtained extrapolating the graph of $\eta_{\text {sp }} / c$ vs. $c$ to zero concentration.

\section{4 Adsorption and desorption of HSA}

HSA was dissolved in $10^{-3} \mathrm{M} \mathrm{KNO}_{3}$ solution at concentrations of 0.05 to $2 \mathrm{~g} / \mathrm{dm}^{3}$. The initial $\mathrm{pH}\left(\mathrm{pH}_{\mathrm{ini}}\right)$ of the HSA solution was adjusted in the range of 2.7 to 9.2 with $0.1 \mathrm{M} \mathrm{HNO}_{3}$ and $0.1 \mathrm{M} \mathrm{KOH}$. A 5-ml aliquot of HSA solutions was introduced into $25-\mathrm{dm}^{3}$ glass vials containing $0.5 \mathrm{~g}$ of titanium particles. Each vial was then sealed with a butyl rubber stopper, laid on its side in a water bath at $40{ }^{\circ} \mathrm{C}$, and reciprocally shaken $(140$ oscillations per min) for $2 \mathrm{~h}^{8)}$. After being shaken, the vial was centrifuged at $2,300 \times g$ for $10 \mathrm{~min}$. The supernatant containing nonadsorbed HSA was carefully discarded using a micropipette. The HSA-adsorbed titanium particles were washed twice with $5 \mathrm{~mL}$ of $10^{-3} \mathrm{M} \mathrm{KNO}_{3}$ solution by centrifugation $(2300 \times g$ for $10 \mathrm{~min}$ ). After being washed twice, the particles were dried at $40{ }^{\circ} \mathrm{C}$ for $16 \mathrm{~h}$. The dried particles were transferred into another glass vial and the amount of adsorbed HSA $(\Gamma)$ was determined as the sum of the amount of HSA removed and that of HSA still remaining on the particles $\left(S_{\mathrm{r}}\right)$ after batchwise treatment with $0.1 \mathrm{M} \mathrm{NaOH}$ for $2 \mathrm{~h}$ with shaking (140 oscillations per min) as described previously ${ }^{16}$. HSA in solution or on titanium particles was measured by Lowry-Folin method ${ }^{17)}$.

To determine the effect of the $\mathrm{pH}$ of cleaning solution on the removal of HSA from titanium particle, cleaning solutions of $\mathrm{pH}_{\text {ini }} 1$ to 13 , which was adjusted with $0.1 \mathrm{M} \mathrm{HNO}_{3}$ and $\mathrm{KOH}$ solution, were used. A 0.5 -g portion of HSA-adsorbed titanium particles $\left(2.2 \mathrm{mg} / \mathrm{m}^{2}\right)$, prepared at $\mathrm{pH}_{\text {ini }} 7.4$, and $0.005 \mathrm{dm}^{3}$ of cleaning solutions were put into $25-\mathrm{dm}^{3}$ glass vials, and then vials were reciprocally shaken (140 oscillations per min) at $40{ }^{\circ} \mathrm{C}$ for $2 \mathrm{~h}$ as described above. The removal efficiency was expressed as the ratio of the amount of HSA desorbed to the initial amount of HSA adsorbed.

\section{Results and discussions}

\section{1 Characterization of charging behavior of HSA and titanium}

Figure 1 shows the curves for the $Z_{\mathrm{H}^{+}}$app at different $\mathrm{KNO}_{3}$ concentrations and the $[\eta]$ in $10^{-3} \mathrm{M} \mathrm{KNO}_{3}$ solution as a function of $\mathrm{pH}$. The $Z_{\mathrm{H}^{+} \text {app }}$ and the $[\eta]$ reflect the relative degree of ionization of functional groups and molecular volume of HSA in an aqueous solution, respectively. The $\mathrm{pzc}_{\mathrm{app}}$ was found to be 5.4. The absolute value of the $Z_{\mathrm{H}^{+}}$app tended to increase with increasing $\mathrm{KNO}_{3}$ concentrations.

The $[\eta]$ also depended on the solution pH (Fig. 1B). The minimum $[\eta]$ value of $2.6 \times 10^{-3} \mathrm{dm}^{3} / \mathrm{g}$ was obtained at $\mathrm{pH} 5.3$, i.e., around the $\mathrm{pzc}_{\mathrm{app}}$ of HSA. With increasing difference in $\mathrm{pH}$ values from the $\mathrm{pzc}_{\text {app }}$, the $[\eta]$ value increased significantly. The $[\eta]$ values obtained in the $\mathrm{pH}$ range of 6.6 to $7.4,3.6 \times 10^{-3}$ to $5.0 \times 10^{-3} \mathrm{dm}^{3} / \mathrm{g}$, were in good agreement with the value $(4.62$ $\times 10^{-3} \mathrm{dm}^{3} / \mathrm{g}$ at $\mathrm{pH} 7.0$ ) reported by Monkos ${ }^{18)}$. It was clear that the $[\eta]$ value was correlated with the $Z_{\mathrm{H}^{+}}$app value. A small $Z_{\mathrm{H}^{+}}$app results in contraction of the molecule, whereas a large $Z_{\mathrm{H}^{+}}$app brings about intramolecular electrostatic repulsion, thereby leading to expansion of the molecule. The reversible expansion of globular proteins is general feature ${ }^{11), 15), 19)}$. The $[\eta]$ value also gives information related to the area occupied by HSA in the adsorbed state.

Figure 2 shows the curves for the $\sigma_{\text {app }}$ of titanium particles as a function of $\mathrm{pH}$. The $\sigma_{\text {app }}$ of titanium surfaces showed acidic
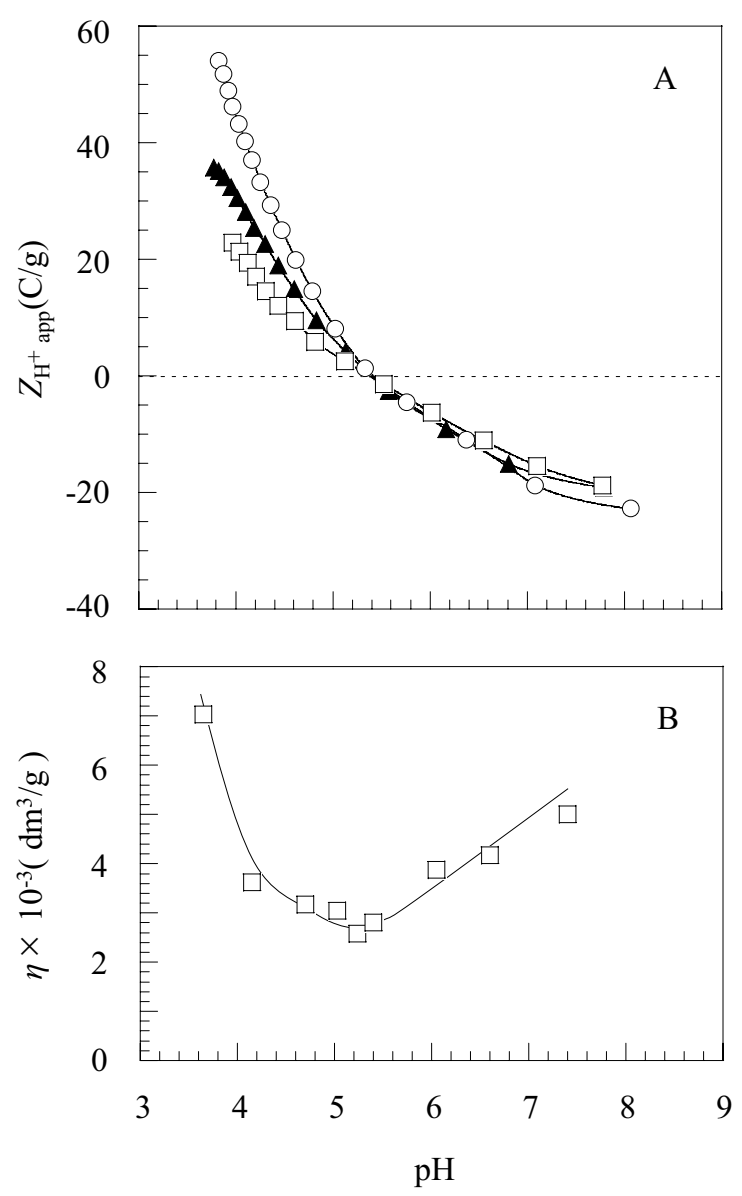

Fig. 1 Curves for the $Z_{\mathrm{H}^{+} \text {app }}(\mathrm{A})$ and the $[\eta]$ (B) of HSA at different $\mathrm{KNO}_{3}$ concentrations, as a function of $\mathrm{pH}$.Symbols $\left(\mathrm{KNO}_{3}\right): \bigcirc, 10^{-1} \mathrm{M} ; \boldsymbol{\Delta}, 10^{-2} \mathrm{M} ; \square, 10^{-3} \mathrm{M}$. 
nature that was characterized by small positive $\sigma_{\text {app }}$ values and large negative $\sigma_{\text {app }}$ values. The $\mathrm{pzc}_{\text {app }}$ was found to be 4.4 , which was in agreement with the values (4.4 to 6.2) reported for Ti and $\mathrm{TiO}_{2}$ particles ${ }^{8)}$.

\section{2 Effect of $\mathbf{p H}$ on HSA adsorption}

Figure 3 shows the typical isotherm for HSA adsorption on titanium particles at $\mathrm{pH}_{\text {ini }} 7.4$ which is equal to blood $\mathrm{pH}$. The $\Gamma$ increased greatly at low equilibrium concentrations of HSA $\left(c_{\mathrm{HSA}}\right)$ and reached saturation value $\left(\Gamma_{\mathrm{sat}}\right)$ of $2.2 \mathrm{mg} / \mathrm{m}^{2}$ at $c_{\mathrm{HSA}}$ more than $0.2 \mathrm{~g} / \mathrm{dm}^{3}$. When the $\Gamma$ value was less than $1.8 \mathrm{mg} / \mathrm{m}^{2}$, $c_{\mathrm{HSA}}$ values were almost zero. This indicates that HSA molecules in solution were almost completely adsorbed on titanium. Such high affinity-type isotherms with well-defined saturation values were obtained in the $\mathrm{pH}$ range of 2.7 to 7.5 (data not shown). When all the HSA-adsorbed titanium particles obtained at examined $\mathrm{pHs}$ were washed with $10^{-3} \mathrm{M} \mathrm{KNO}_{3}$ solution at $40{ }^{\circ} \mathrm{C}$ for 2 $\mathrm{h}$, no desorption of HSA occurred, indicating that the adsorption of HSA on titanium was irreversible.

Figure 4A shows the $\Gamma_{\text {sat }}$ values as a function of $\mathrm{pH}_{\text {ini. }}$. The $\Gamma_{\text {sat }}$ depended on the $\mathrm{pH}_{\text {ini. }}$. The maximum value of $\Gamma_{\text {sat }}$ was $3.8 \mathrm{mg} / \mathrm{m}^{2}$ and obtained at $\mathrm{pH}$ around the $\mathrm{pzc}_{\text {app }}$ of HSA (5.4) and little $\mathrm{pH}$ change followed by the HSA adsorption was occurred at this $\mathrm{pH}$. The obtained $\Gamma_{\text {sat }}$ corresponded to the values $\left(3.0\right.$ to $\left.3.6 \mathrm{mg} / \mathrm{m}^{2}\right)$ reported for monolayer adsorption of $\mathrm{HSA}^{10), 11)}$. The occurrence

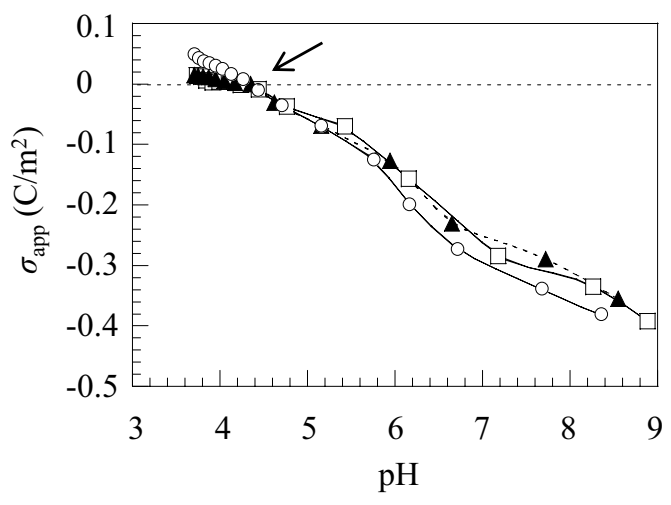

Fig. 2 Curves for the $\sigma_{\text {app }}$ of titanium particles at different $\mathrm{KNO}_{3}$ concentrations, as a function of $\mathrm{pH}$. The arrow indicates pzc app. Symbols $\left(\mathrm{KNO}_{3}\right): \bigcirc$, $10^{-1} \mathrm{M} ; \boldsymbol{\Delta}, 10^{-2} \mathrm{M} ; \square, 10^{-3} \mathrm{M}$.

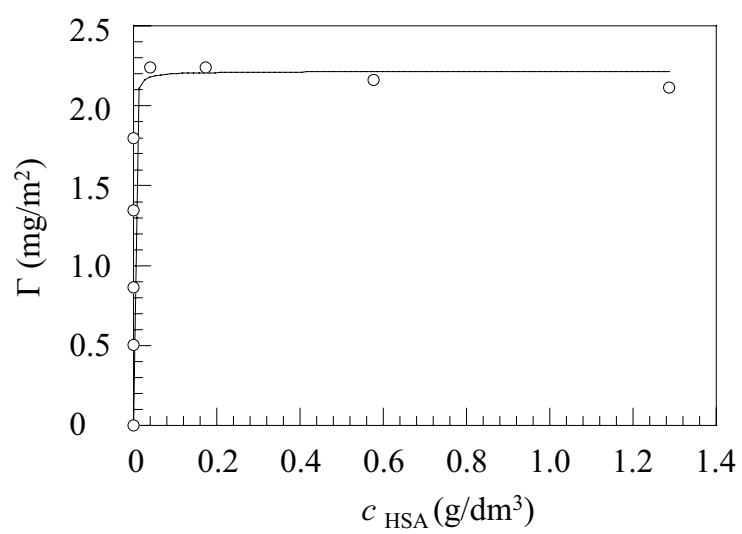

Fig. 3 Isotherm for HSA adsorption on titanium particles at $40{ }^{\circ} \mathrm{C}$ and at $\mathrm{pH}_{\text {ini }}$ 7.4. The adsorption experiment wasconducted in the presence of $10^{-3} \mathrm{M} \mathrm{KNO}_{3}$ with reciprocalshaking for $2 \mathrm{~h}$ (140 oscillations per min). of an adsorption maximum of albumin protein in their pzc region is also commonly found on various solid surfaces ${ }^{8), 10), 15), 20), 21)}$. Even when HSA had the same type of net charge as that of titanium, the adsorption of HSA took place spontaneously. Since HSA molecule behaves as soft particles with ion-penetrable layers $^{11), 22)}$, the electrostatic repulsion between HSA and titanium is thought to be extremely low or negligible upon adsorption. Thus, although global electrostatic forces undoubtedly affect adsorption behavior, they do not dominate the $\Gamma_{\text {sat }}$. In the case of protein adsorption, the contribution of electrostatic repulsive forces might become important for the interaction between HSA molecules. The magnitude of $Z_{\mathrm{H}^{+}}$app determines molecular structure and strength of electrostatic repulsive forces. A small $Z_{\mathrm{H}^{+}}$app, and hence a small $[\eta]$ enables HSA molecules to form a closely-packed adsorbed layer on titanium surfaces because lateral electrostatic repulsions between adjacent HSA molecules are minimized. As a result, a large $\Gamma_{\text {sat }}$ is obtained at $\mathrm{pH}$ around the $\mathrm{pzc}_{\text {app }}$ of HSA. At pHs far from the $\mathrm{pzc}_{\text {app }}$ of HSA, a large $Z_{\mathrm{H}^{+}}$app causes molecular expansion of HSA and intermolecular electrostatic repulsion between HSA molecules, thereby resulting in a sparse arrangement of HSA on titanium and a small $\Gamma_{\text {sat. }}$ It is indicated that the $Z_{\mathrm{H}^{+}}$app and $[\eta]$ of HSA are the most important factors determining the $\Gamma_{\text {sat }}$ value, aside from the magnitude of interaction forces between HSA and titanium surfaces.

The HSA-adsorbed titanium particles at $\Gamma_{\text {sat }}$ obtained in Fig. 4A were washed with $0.1 \mathrm{M} \mathrm{NaOH}$ solution and the amounts of HSA remaining on titanium $\left(S_{\mathrm{r}}\right)$ were compared as a function of the adsorption $\mathrm{pH}$ (Fig. 4B). Although there were significant differences in the $\Gamma_{\text {sat }}$ depending on the adsorption $\mathrm{pH}$, the $S_{\mathrm{r}}$ values were almost equal to each other $\left(0.34 \pm 0.03 \mathrm{mg} / \mathrm{m}^{2}\right)$. These data indicate that a certain amount of HSA molecules, that are not able to be removed by cleaning with $0.1 \mathrm{M} \mathrm{NaOH}$, are present irrespective of $\mathrm{pH}_{\text {ini }}$ and the $\Gamma_{\text {sat }}$ values.

\section{3. $3 \sigma_{\text {app }}$ of HSA-adsorbed titanium}

Experiments were designed to investigate the type of ionic groups on HSA molecule interacting with titanium surfaces. The HSA-adsorbed titanium particles were prepared at $\mathrm{pH} 7.4(\Gamma=$ $2.2 \mathrm{mg} / \mathrm{m}^{2}$ ), where HSA and titanium have net negative charges,

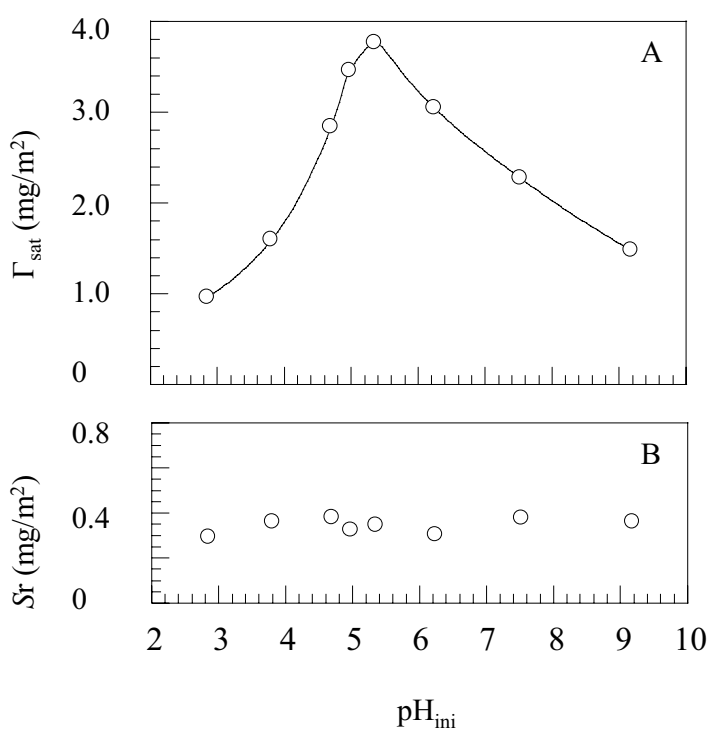

Fig. 4 Effect of adsorption initial $\mathrm{pH}$ on the $\Gamma_{\text {sat }}$ values over the $\mathrm{pH}$ range of 2.8 to 9.2 . For experimental conditions, see the legend for Fig. 3. 
and the dried particles were titrated in the presence of $10^{-1} \mathrm{M}$ $\mathrm{KNO}_{3}$. Figure 5 shows curve for the $\sigma_{\text {app }}$ of the HSA-adsorbed titanium particles as a function of $\mathrm{pH}$. The dotted line was the curve obtained by summing the $\sigma_{\text {app }}$ of titanium particles per $\mathrm{m}^{2}$ and the $Z_{\mathrm{H}^{+}}$app per $2.2 \mathrm{mg}$ at $10^{-1} \mathrm{M} \mathrm{KNO}_{3}$. If there was no electrostatic interaction between adsorbed HSA and titanium surface, the curve for $\sigma_{\text {app }}$ of HSA-adsorbed titanium particles coincides with the dotted line. However, the curve for $\sigma_{\text {app }}$ shifted to the positive side, giving the more alkaline $\operatorname{pzc}_{\text {app }}$ (5.9) compared with the calculated pzc $_{\text {app }}$ (5.0) of HSA-adsorbed titanium particles. It was noted that the difference in the $\sigma_{\text {app }}$ values between solid line and dotted line increased gradually with increasing $\mathrm{pH}$ from $\mathrm{pH} 4$ to $\mathrm{pH}$. This result suggested that the number of titratable free ionic groups on HSA or on titanium, which release protons in the $\mathrm{pH}$ range of 4 to 7 , decreased probably due to interactions between HSA and titanium.

HSA is composed of 585 amino acids (molecular weight: $66,500)$ and it has 105 units of $\beta$-, $\gamma$-carboxyl groups and 60 units of $\varepsilon$-amino groups as the main acidic and basic ionic groups ${ }^{11)}$. The dissociation constants $\left(\mathrm{p} K_{\mathrm{a}}\right)$ of $\beta$-, $\gamma$-carboxyl (Asp and Glu) and $\varepsilon$-amino (Arg, Lys), main acidic and basic groups on HSA, were 4.0 and 9.4 , respectively ${ }^{23)}$. In the $\mathrm{pH}$ range of 4 to 7 , carboxyl groups dissociate with the increase in $\mathrm{pH}\left(-\mathrm{COO}^{-}\right.$, molar ratio: $\alpha=0.5$ to 1.0$)$, whereas amino groups remain protonated form $\left(-\mathrm{NH}_{3}{ }^{+}, \alpha=1.0\right)$. On the other hand, since it is assumed that the $\mathrm{p} K_{\mathrm{a}}$ of acidic and basic $\mathrm{OH}$ groups on titanium are situated at $1.4 \mathrm{pH}$ unit away from the $\mathrm{pzc}_{\text {app }}$ (4.4) of titanium ${ }^{24)}$, a major fraction of acidic $\mathrm{OH}$ groups are present as the dissociated form, releasing protons $\left(-\mathrm{Ti}_{2} \mathrm{O}^{-}\right)$, whereas the ratio of deprotonated form $\left(-\mathrm{TiO}^{-}\right)$of basic $\mathrm{OH}$ groups to the neutral form $(-\mathrm{TiOH})$ increase with the increase in $\mathrm{pH}$ over the $\mathrm{pH}$ range of 4 to 7 . Accordingly, proton-releasing titratable ionic groups in the $\mathrm{pH}$ range of 4 to 7 seem carboxyl groups of HSA, and acidic and basic $\mathrm{OH}$ groups on titanium particles. At this point it has been known that the curve for the $\sigma_{\text {app }}$ of protein-adsorbed solid particles was more affected by the degree of shift in acid-base equilibria on the adsorbed protein molecule rather than by solid surface nature ${ }^{13), 20}$. These findings suggest that dissociation of part of carboxyl groups on HSA is prevented probably due to the interaction with basic $\mathrm{OH}$ groups on titanium surfaces in the titration system of the HSA-adsorbed

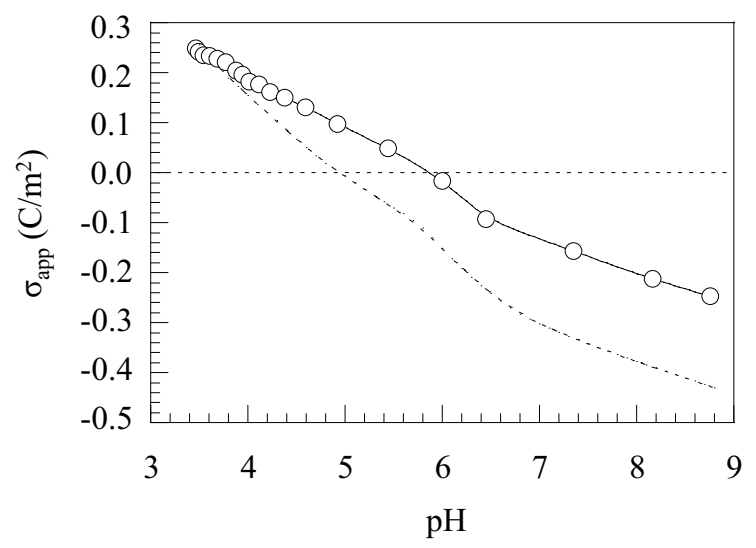

Fig. 5 Curve for the $\sigma_{\text {app }}$ of HSA-adsorbed titanium particles fouledat $\Gamma$ of $2.2 \mathrm{mg} / \mathrm{m}^{2}$ as a function of $\mathrm{pH}$. Titration was conducted in thepresence of $10^{-1} \mathrm{M} \mathrm{KNO}_{3}$. Dotted line denotes the calculation curvederived summing of the $\sigma_{\text {app }}$ of titanium and $\mathrm{Z}_{\mathrm{H}^{+} \text {app }}$ of $2.2 \mathrm{mg}$ of HSA. titanium particles.

\section{4 Uptake and release of proton upon adsorption}

To elucidate the types of interactions between HSA and titanium, we designed the experiments to measure the variation in $\mathrm{pH}$ of solutions $(\Delta \mathrm{pH})$ as a result of adsorption. It is assumed that positive value of $\Delta \mathrm{pH}$ is attributed to release of $\mathrm{OH}^{-}$(or uptake of $\mathrm{H}^{+}$) during the adsorption process, and negative value of $\Delta \mathrm{pH}$ is attributed to release of $\mathrm{H}^{+}$to the solution. Figure 6A shows $\Delta \mathrm{pH}$ as a function of $\mathrm{pH}_{\text {ini. }}$ The $\Delta \mathrm{pH}$ was zero at $\mathrm{pH} 5.2$, below which it was slight positive value and above which negative value. Based on these data, the magnitude of variation in $\mathrm{H}^{+}$concentration $\left(\Delta \mathrm{H}^{+}\right)$was calculated (Fig. 6B). At $\mathrm{pHs}$ less than $5.2, \Delta \mathrm{H}^{+}$became large negative values with decreasing $\mathrm{pH}$, indicating that uptake of $\mathrm{H}^{+}$occurred upon adsorption. On the other hand, in the $\mathrm{pH}_{\text {ini }}$ range of 5.2 to 9.2 , the absolute values of positive $\Delta \mathrm{H}^{+}$were extremely low, indicating that only a slight release of $\mathrm{H}^{+}$occurred. It is of interest that the $\mathrm{pH}$ giving $\Delta \mathrm{H}^{+}$ $=0$ was observed near the $\mathrm{pzc}_{\mathrm{app}}$ (5.4) of HSA.

\section{5 Interactions between HSA and titanium}

The main possible interaction types between protein and metal surface are known to be electrostatic (ion-ion and dipole-dipole) interactions, hydrogen bonding, and ligand exchange $\mathrm{e}^{8,11), 15}$. Considering the results in Fig. 5 and Fig. 6, we proposed the probable reactions between HSA and titanium according to the investigation by Oliva et $\mathrm{al}^{11}$.

At $\mathrm{pH} 7.4$, human blood $\mathrm{pH}$, the predominant acidic and basic $\mathrm{OH}$ groups on titanium are $-\mathrm{Ti}_{2} \mathrm{O}^{-}(\alpha=1.0)$ and $-\mathrm{TiOH}(\alpha=$ ca. $1.0)$, respectively, while the main functional groups on HSA are $-\mathrm{COO}^{-}(\alpha=1.0)$ and $-\mathrm{NH}_{3}{ }^{+}(\alpha=1.0)$. Judging from the fact that the $\Delta \mathrm{H}^{+}$was slight positive value (Fig. 6B), some possible reactions are proposed as follows:

$$
-\mathrm{Ti}_{2} \mathrm{O}^{-}+\mathrm{R}-\mathrm{NH}_{3}{ }^{+} \rightarrow-\mathrm{Ti}_{2} \mathrm{O}^{-+} \mathrm{NH}_{3}-\mathrm{R}
$$

(1) [ion-ion interaction]
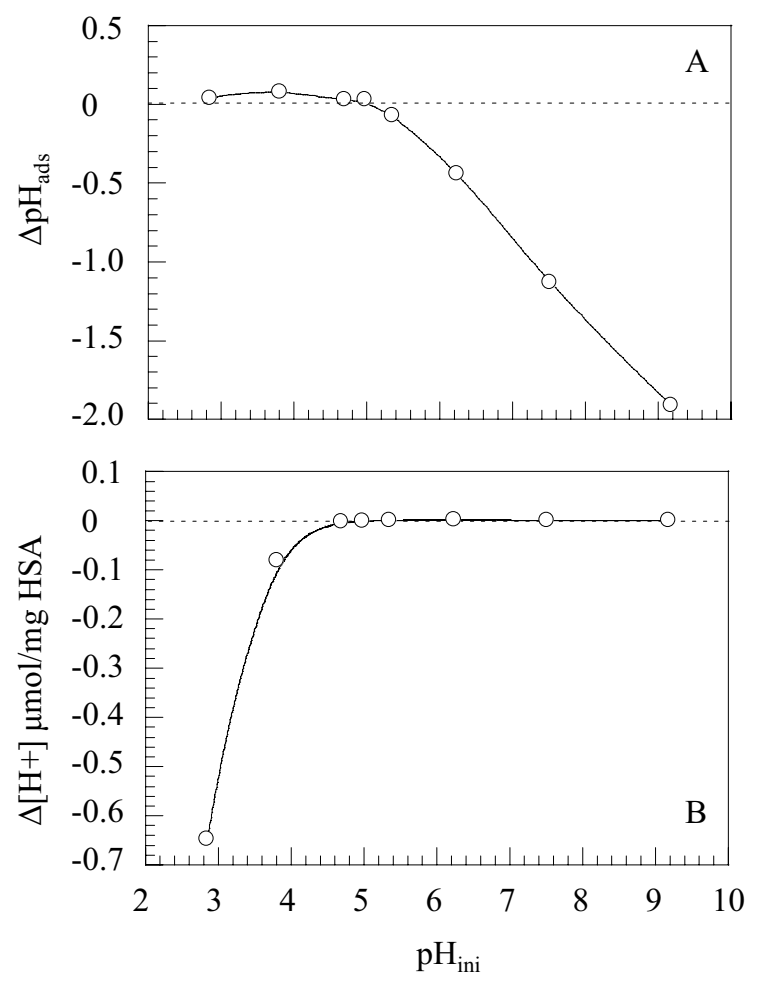

Fig. 6 The $\Delta \mathrm{pH}(\mathrm{A})$ and $\Delta[\mathrm{H}+]$ (B) upon HSA adsorption on titanium particles as a function of $\mathrm{pH}_{\text {ini. }}$. 


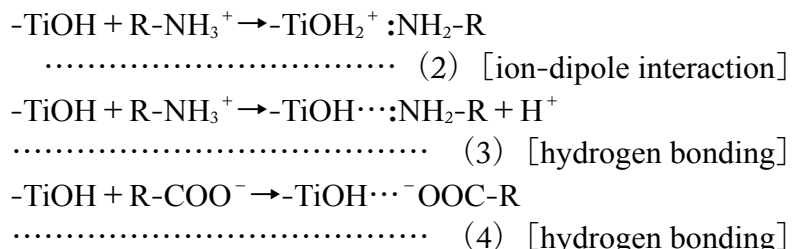

(4) [hydrogen bonding]

Although type of reaction involving carboxylic groups is lesser than those involving amino groups, the large number of carboxylic groups (105 units) can contribute to many points of attachment with titanium surfaces via hydrogen bonding. It is likely that reaction (4) is responsible for the shift in the $\sigma_{\text {app }}$ curve of HSA-adsorbed titanium to the positive side as shown in Fig. 5. Presumably, reactions (1) to (4) would dominate the adsorptive interactions in the $\mathrm{pH}_{\text {ini }}$ range of 5.4 to 9.2.

In the $\mathrm{pH}$ range of 2.8 to 5.4 , titanium surfaces were positively and negatively charged within ca. $\pm 0.1 \mathrm{C} / \mathrm{m}^{2}$ on the acidic and basic sides of its $\mathrm{pzc}_{\text {app. }}$. In this $\mathrm{pH}$ region, it is thought that $-\mathrm{Ti}_{2} \mathrm{OH}$ and $-\mathrm{Ti}_{2} \mathrm{O}^{-}$, and $-\mathrm{TiOH}$ and $-\mathrm{TiOH}_{2}{ }^{+}$coexisted as the acidic and basic $\mathrm{OH}$ groups, respectively. On the other hand, the main functional groups on HSA are $\mathrm{COO}^{-}(\alpha=0.2$ to 1$)$ and $-\mathrm{NH}_{3}{ }^{+}(\alpha=1.0)$. Since polarity of dissociated carboxyl groups is higher than protonated amino groups, carboxyl groups are thought to be highly reactive with the basic $\mathrm{OH}$ groups on titanium. On the acidic side of the pzc app $(5.4)$ of $\mathrm{HSA}$, the $\Delta \mathrm{H}^{+}$ was large negative values (Fig. 6B), indicating uptake of $\mathrm{H}^{+}$ or release of $\mathrm{OH}^{-}$. Apart from reactions (1) to (4), other most probable reactions are as follows:

$$
\begin{aligned}
& -\mathrm{TiOH}+\mathrm{R}-\mathrm{COO}^{-}+\mathrm{H}_{2} \mathrm{O} \rightarrow-\mathrm{TiOH}_{2}{ }^{+-} \mathrm{OOC}-\mathrm{R}+\mathrm{OH}^{-} \\
& \text {(5) [ion-ion interaction] } \\
& -\mathrm{Ti}_{2} \mathrm{O}^{-}+\mathrm{R}-\mathrm{COO}^{-}+\mathrm{H}_{2} \mathrm{O} \rightarrow-\mathrm{Ti}_{2} \mathrm{OH}{ }^{\cdots}{ }^{-} \mathrm{OOC}-\mathrm{R}+\mathrm{OH}^{-} \\
& \text {(6) [hydrogen bonding] } \\
& -\mathrm{TiOH}+\mathrm{R}-\mathrm{COO}^{-} \rightarrow-\mathrm{TiOOC}_{-} \mathrm{R}+\mathrm{OH}^{-} \\
& \text {(7) [ligand exchange] } \\
& -\mathrm{TiOH}+\mathrm{R}-\mathrm{COOH} \rightarrow-\mathrm{TiOOC}-\mathrm{R}+\mathrm{H}_{2} \mathrm{O} \\
& \text { (8) [ligand exchange] } \\
& -\mathrm{TiOH}_{2}{ }^{+}+\mathrm{R}-\mathrm{COO}^{-} \rightarrow-\mathrm{TiOOC}-\mathrm{R}+\mathrm{H}_{2} \mathrm{O} \\
& \text { (9) [ligand exchange] }
\end{aligned}
$$

The strength of binding force per bond increases in the order

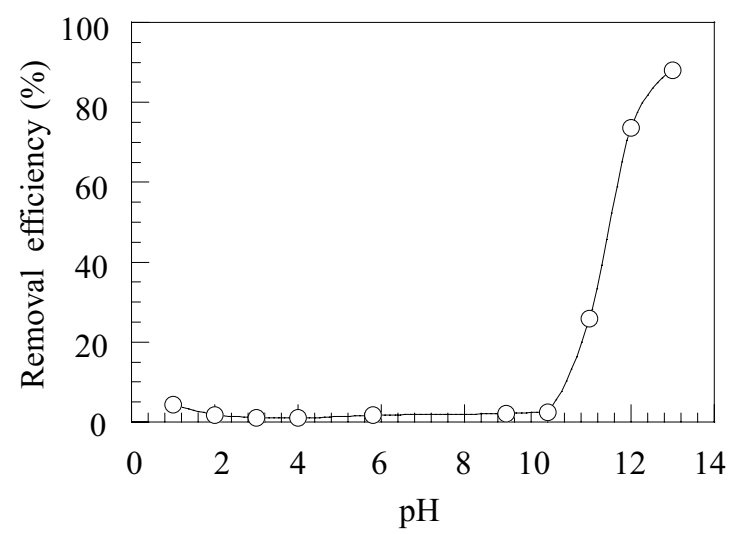

Fig. 7 Effect of the pH of cleaning solution on the HSA removal from titanium particles. Batchwise cleaning experiment was conducted at $40^{\circ} \mathrm{C}$ for $2 \mathrm{~h}$ with shaking (140 oscillations per min). The $\mathrm{pH}$ of cleaning solutionwas adjusted with $0.1 \mathrm{M} \mathrm{HNO}_{3}$ and $\mathrm{KOH}$ solution. HSA from titanium particle, the 0.5 -g portion of HSA-adsorbedtitanium particles were prepared at $\mathrm{pH}_{\mathrm{ini}}$ $7.4\left(\Gamma=2.2 \mathrm{mg} / \mathrm{m}^{2}\right)$. hydrogen bonding $<$ electrostatic interaction $<$ ligand exchange. In addition, there are stronger electrostatic interactions between carboxyl groups on HSA and basic $\mathrm{OH}$ groups on titanium compared with those between amino groups and $\mathrm{OH}$ groups on titanium $^{8), 12)}$. However, the $S_{\mathrm{r}}$ values after cleaning with $0.1 \mathrm{M}$ $\mathrm{NaOH}$ were almost equal to each other irrespective of the adsorption $\mathrm{pH}$ (Fig. 4B). It is presumed that, although the global binding strength of HSA to negatively charged titanium surfaces is relatively low on the basic side of the $\mathrm{pzc}_{\text {app }}$ of HSA, strongly bound HSA molecules coexist in the adsorbed layer due to a multipoint attachment or possibly a variety of surface interactions.

\section{6 Effect of the $\mathrm{pH}$ of cleaning solution on the HSA removal}

Figure 7 shows the effect of the $\mathrm{pH}$ of cleaning solution on the removal efficiency of HSA from titanium particles $(\Gamma=$ $2.2 \mathrm{mg} / \mathrm{m}^{2}$ at $\left.\mathrm{pH}_{\mathrm{ini}} 7.4\right)$. The removal efficiency was considerably higher when using the alkali cleaning solution than when using the acidic cleaning solution. At pHs above $\mathrm{pH}$ 10, the removal efficiency increased markedly with increasing $\mathrm{pH}$. A small amount of HSA was removed from titanium by a cleaning with acidic solution of $\mathrm{pH} 1$. In the $\mathrm{pH}$ range of 2 to 10 , only a small or no HSA removal was observed. These phenomena indicate the availability of $\mathrm{OH}^{-}$ions in removing HSA from titanium surfaces. Adsorption of $\mathrm{OH}^{-}$ions at the HSA-titanium contact region can make their surfaces more negative, thereby diminish or minimize the magnitude of forces of interactions between HSA and titanium (reactions 1 to 9) but not completely. It was noted that the HSA removal occurred markedly at alkaline $\mathrm{pH}$ region above the $\mathrm{p} K_{\mathrm{a}}$ values of side-chain $\varepsilon$-amino groups ( $\mathrm{pH}$ 9.4), phenolic $\mathrm{OH}$ groups $(\mathrm{pH} 10.4)$, and guanidyl groups $(\mathrm{pH}>12)$. In alkaline $\mathrm{pH}$ regions above 10 , the $Z_{\mathrm{H}^{+}}$app of HSA is expected to become large negative value. As well as the electrostatic repulsion between HSA and titanium, the swollen structure of HSA arising from intramolecular repulsion is the driving force to transport HSA from titanium surfaces to the solution.

\section{Conclusions}

In this study, the factors determining the $\Gamma_{\text {sat }}$ value HSA on titanium and the type of interaction between HSA and titanium were investigated. It was confirmed that the $Z_{\mathrm{H}^{+} \text {app }}$ and $[\eta]$ of HSA were the most important factors determining the $\Gamma_{\text {sat }}$ value. HSA was adsorbed on titanium surfaces even under unfavorable electrostatic conditions through a variety of interactions between ionic groups on HSA and surface $\mathrm{OH}$ groups on titanium. The high removal efficiency of HSA from titanium surfaces was obtained by cleaning with alkaline solutions, particularly of $\mathrm{pHs}$ above 11 which is higher than the $\mathrm{p} K_{\mathrm{a}}$ values of basic side-chain functional groups on HSA.

(Received January 5, 2010 ; Accepted April 25, 2010)

\section{References}

1) A. Klinger, D. Steinberg, D. Kohavi, M. N. Sela ; J. Biomed.Mater. Res., 36, 387 (1997).

2) M.C.Sunny, C. P. Sharma ; J. Biomater. Appl., 6, 89 (1991).

3) B. Wälivaara, B. O. Aronsson, M. Rodahl, J. Lausmaa, P. Tengvall ; Biomaterials, 15, 827 (1994).

4) E. M. Hetrick, M. H. Schoenfisch ; Chemical Society Reviews, 35, 780 (2006).

5) F. David; Titanium in medicine: material science, surface science, engineering, biological response and medical applications, p.13 
(Springer Verlag, 2001).

6) J.C. Wataha ; The Journal of Prosthetic Dentistry, 83, 223 (2000).

7) H. P. Boehm ; Disc. Faraday Soc., 52, 264 (1971).

8) K. Takahashi, S. Fukuzaki ; Biocontrol Sci., 13, 9 (2008).

9) M. Textor, C. Sittig, V. Frauchiger,S. Tosatti, D. M. Brunette ; Titanium in medicine: material science, surface science, engineering, biological response and medical applications, p.171 (Springer Verlag, 2001).

10) C.A. Haynes, W. Norde ; Colloids surface B, Biointerfaces, 2, 517 (1994).

11) F.Y. Oliva, L. B. Avalle, O. R. Cámara, C. P. De Pauli ; J. Colloid Interface Sci., 261, 299 (2003).

12) K. Imamura, M. Shimomura, S. Nagai, M. Akamatsu, K. Nakanishi ; J. Biosci. Bioeng., 106, 273 (2008).

13) H. Urano, S. Fukuzaki ; J. Biosci. Bioeng., 90, 105 (2000).

14) J. Lyklema ; J. colloid interface sci.. 99, 109 (1984).

15) S. Fukuzaki, H. Urano, K. Nagata ; J. Ferment. Bioeng., 80, 6
(1995).

16) S. Fukuzaki, H. Urano, M. Hiramatsu, A. Takehara ;. Biocontrol sci., 6, 87 (2001).

17) O. H. Lowry, N. J. Rosebrough; A. L. Farr, R., J. Randall ; J. Biological Chem., 193, 265 (1951).

18) K. Monkos ; Biochim. Biophys. Acta, 1700, 27 (2004).

19) C. Tanford, J. G. Buzzell, D. G. Rands, S. A. Swanson ; J. Am. Chem. Soc., 77, 6421 (1955).

20) S. Fukuzaki, H. Urano, K. Nagata ; J. Ferment. Bioeng., 81, 163 (1996).

21) W. Norde, J. Lyklema ; J. Colloid Interface Sci., 66, 257 (1978).

22) H. Oshima ; Adv. Colloids Interface Sci., 62, 189 (1995).

23) C. Tanford ; J. Am. Chem. Soc., 72, 441 (1950).

24) P. W. Schindler, H. Gamsjäger ; Colloid Polymer Sci., 250,\$ \$759 (1972).

25) K. Imamura, Y. Kawasaki, T. Nagayasu T. Sakiyama, K. Nakanishi ; J. Biosci. Bioeng., 103, 7 (2007). 